\title{
Isolat Bakteri Asam Laktat Sebagai Probiotik dengan Vaksinasi AI dan ND dalam Pembentukan Titer Antibodi Dan Bobot Badan Ayam Jantan Tipe Medium
}

\section{Isolate Lactic Acid Bacteria As Probiotics With AI And ND Vaccination In The Formation of Body Weight And Antibody Titers of Male Chickens Medium Type}

\author{
Rudy Sutrisna
}

\author{
Jurusan Peternakan Fakultas Pertanian Universitas Lampung \\ Jln. Soemantri Brojonegoro No. 1 Bandar Lampung
}

\begin{abstract}
Isolates of Lactic Acid Bacteria isolates assembled into a mixture of LAB as probiotics . LAB probiotic drops introduced through the mouth with the aim of suppressing pathogens and is expected to improve the health status of rooster type of medium . Isolates in the digestive tract will undergo adaptation by temperature, acidity and $\mathrm{pH}$ changes in the gut. The health status of the chicken can be expressed as growth to form the body weight, and the growth of LAB . In addition, AI and ND vaccination in healthy chickens conditions will produce antibodies to both. The success of vaccination can be evaluated from the results of the formation of chicken blood serum titre of research. Analysis of descriptive data on the dynamics of the growth of LAB, the formation of antibody titer and body weight gain 24-31 day old chickens . Based on the results of this study revealed that isolates of LAB can be used simultaneously in bercoccidiostat feed . LAB isolates may develop in the digestive tract rooster medium type as probiotics. The dynamics of the growth of a population produces a mixture of isolates of $\mathrm{LAB}$ isolates (mixture of $\mathrm{B} 1, \mathrm{~B} 3, \mathrm{~B} 4, \mathrm{~B} 5$ as probiotics) in the highest reaches of the ilium and jejunum $14.00 \times 10-613.5 \times 10-6 \mathrm{CFU} / \mathrm{ml}$. Test isolates viability of probiotic candidates in all isolates produced distilled water medium can live up to 72 hours of incubation. In addition, there is a synergy results in the formation of antibody titers ND uniform T3 treatment. T3 treatment is given probiotics $2 \mathrm{x}$ chicken every week for 3 weeks. In AI vaccination resulted in antibody titers are not uniform. Body weight gain reached the age of 24-31 days in a row $75.83 \mathrm{~g}, 76.54 \mathrm{~g}$, $81.58 \mathrm{~g}, 87.04 \mathrm{~g}$. Weight age of 31 days the average value obtained successively from the highest $329.16 \mathrm{~g}, 328.54 \mathrm{~g}, 325.54 \mathrm{~g}$ and $324.08 \mathrm{~g}$ lowest .
\end{abstract}

Keywords; isolates LAB, probiotics, antibody titers, rooster layer medium type.

Diterima: 30-10-2013, disetujui: 02-05-2014 

Rudy Sutrisna: Isolat Bakteri Asam Laktat Sebagai Probiotik dengan Vaksinasi AI Dan ND...

\section{PENDAHULUAN}

Bakteri Asam Laktat (BAL) terdapat di saluran pencernaan ayam/itik (indogenous) dapat diisolasi dan digunaan sebagai probiotik. Introduksi isolat BAL asal saluran pencernaan unggas lebih adaptif jika diaplikasikan dalam saluran pencernaan ayam yang juga berasal dari unggas. Isolat BAL diharapkan dapat menyeimbangkan antara bakteri tidak patogen dengan yang patogen sehingga dapat meningkatkan kesehatan ayam jantan. Jenis BAL yang sering digunakan sebagai starter diantaranya kelompok Lactobaccilus, Leuconostoc, Pediococcus, Enterococcus, Lactococcus, dan Streptococcus.

Seiring perkembangan ilmu dan teknologi, pakan dapat bersifat fungsional. Suatu pakan dikatakan mempunyai sifat fungsional apabila pakan tersebut mengandung komponen baik nutrisi maupun non nutrisi yang bermanfaat terhadap organ-organ dalam tubuh yang relevan untuk menjaga kesehatan atau mempunyai fungsi fisiologis (Roberfroid, 2000). Kelebihan pakan fungsional adalah kemampuannya dalam mencegah terjadinya gangguan kesehatan, karena mengandung komponen bioaktif. Komponen bioaktif dalam pangan maupun pakan fungsional diantaranya adalah prebiotik, probiotik, serat pangan (dietary fiber) dan pati resisten (resistant starch) (Astawan, 2005). Pemeliharaan ayam jantan tipe medium mempunyai kemiripan dengan ayam kampung yaitu untuk mendapatkan bobot tubuh $\pm 1,2 \mathrm{~kg}$ memerlukan waktu 3-4 bulan sedangkan ayam jantan tipe medium 2 bulan. Selain itu, ayam jantan tipe medium memiliki kadar lemak daging rendah, hampir setara ayam kampung, sehingga dapat memenuhi kebutuhan konsumen akan sumber protein kadar lemak rendah.

Menurut Sutrisna dan Nurjanah (2010) mendapatkan total populasi koloni BAL di saluran pencernaan itik di bagian ilium dan sekum secara berurutan populasinya mencapai $107 \times 10^{7}$ dan $50 \mathrm{x}$ $10^{7}$ CFU/g isi ilium dan sekum, sedangkan Mitsuoka (1980), Salanitro (1974) dan Barnes (1986) total bakteri di bagian sekum broiler berkisar antara 10,5-10,9 Log10 CFU/g. Selain bakteri selulolitik dalam saluran pencernaan juga hidup BAL. Oleh karena itu populasi BAL dalam saluran pencernaan ayam jantan perlu diamati diduga menentukan pola pembentukan titer antibodi oleh peningkatan status kesehatan ayam. Bakteri asam laktat dapat berperan sebagai probiotik. Probiotik diharapkan dapat mengoptimalkan daya hidup ayam oleh antibakteri yang dihasilkan. Dengan demikian, status kesehatan yang baik akan dicapai dan menghasilkan antibodi oleh adanya vaksinasi AI dan ND. Selain itu penelitian ini untuk mengetahui titer antibodi yang dapat dibentuk oleh ayam yang divaksin dan diberi probiotik. Pada akhirnya diharapkan mendapatkan pengetahuan tentang adanya hubungan status kesehatan oleh introduksi BAL dengan terbentuknya titer antibodi oleh vaksinasi dan performans ayam jantan tipe medium.

\section{METODE}

Alat-alat yang digunakan dalam penelitian ini antara lain mikroskop, tabung reaksi, gelas objek, tabung anaerobic jar, cawan petri dengan diameter 15 dan $30 \mathrm{~cm}$, erlenmeyer ukuran $500 \mathrm{ml}$, $250 \mathrm{ml}, 100 \mathrm{ml}$ dan $50 \mathrm{ml}$, gelas ukur, ose, spatula, bunsen, vortex mixer, neraca analitik, kompor listrik, autoklaf, laminar air flow, inkubator dengan suhu $41^{\circ} \mathrm{C}$, mikrotube, tip, mikropipet, $\mathrm{pH}$ meter, pipet tetes, dan peralatan lainnya. 
Jurnal Penelitian Pertanian Terapan

Bahan-bahan yang digunakan adalah isolat bakteri usus itik koleksi Sutrisna dan Nurjanah (2010) yaitu (B1, B3, B4, B5). Aquades, aluminium foil, kasa, kapas, minyak imersi. Analisis pembentukan titer antibodi dilakukan pada ayam jantan umur 1-31 hari, dibesarkan dengan diberi ransum komersial ayam jantan (BR1).

\section{Metode Penelitian}

Penelitian ini dilakukan 3 tahap; (1) dinamika pertumbuhan isolat (B1-B5) koleksi Sutrisna dan Nurjanah (2010) dengan menghitung jumlah koloni probiotik yang diintroduksikan melalui tetes mulut pada ayam jantan tipe medium yang diberi ransum BR1 bercoccidiostat dan (2) penentuan titer antibodi oleh adanya vaksinasi AI dan ND pada ayam yang diberi probiotik (isolat BAL B1, B3, B4, B5) dan (3) Bobot badan ayam jantan tipe medium umur 31 hari.

\section{Prosedur Kerja}

\section{Peremajaan Bakteri}

Isolat bakteri usus itik dibiakkan dengan cara digores pada media MRS agar miring diinkubasi pada anaerobic jar selama 48 jam.

\section{Pembuatan Starter}

Isolat yang telah diinkubasi dari peremajaan, diambil masing-masing 1 ose dimasukkan ke dalam cairan McFarland untuk menentukan jumlah koloni 1,5 x 10 8 dalam MRS Broth steril kemudian diinkubasi lagi selama 48 jam digunakan sebagai starter/probiotik.

\section{Uji daya hidup isolat untuk probiotik dalam beberapa media}

Isolat BAL (B1, B3, B4 dan B5), diinkubasi dalam media MRS Broth, bakteri uji diinokulasi sebanyak $1 \mathrm{ml}$ masukkan ke dalam tabung reaksi yang berisi $9 \mathrm{ml}$ untuk masing-masing sampel preparasi pada aquades, lalu dihomogenkan. Suspensi sampel dari pengenceran $10^{-4}$, dan $10^{-8}$ diambil 1 $\mathrm{ml}$ dan dimasukkan secara aseptik masing-masing ke dalam cawan petri steril dan ditambahkan $25 \mathrm{ml}$ media MRS Agar. Cawan petri digoyangkan membentuk angka delapan agar bakteri menyebar merata dan didiamkan hingga memadat. Setelah media memadat, masukkan kedalam inkubator anaerobik jar selama 48-72 jam. Hitung jumlah bakteri yang tumbuh dari masing-masing pengenceran secara duplo.

\section{Uji Serologi (titer antibodi)}

\section{Metode Uji Serologi (Info Medion, 2008)}

Haemaglutination Inhibition (HI) test merupakan metode uji serologi yang telah familiar bagi peternak. Metode uji tersebut seringkali menjadi pilihan bagi peternak. Secara bahasa haemagglutination inhibition dapat diartikan sebagai hambatan haemaglutinasi, sedangkan haemaglutinasi merupakan penggumpalan dari sel darah merah. Kemampuan mengaglutinasi tidak dimiliki oleh semua virus atau bakteri yang menyerang ayam tetapi hanya beberapa virus dan bakteri yang memiliki zat haemaglutinin, diantaranya paramyxovirus (ND), poxvirus (Pox), adenovirus (EDS), orthomyxovirus (AI), bakteri Mycoplasma sp., Haemophilus paragallinarum maupun Salmonella pullorum. Zat haemaglutinin yang terdapat dalam tubuh virus atau bakteri tersebut bersifat antigenik yang dapat merangsang terbentuknya antibodi spesifik. Antibodi yang terbentuk tersebut 
Jurnal Penelitian Pertanian Terapan

memiliki kemampuan menghambat terjadinya aglutinasi darah yang disebabkan oleh haemaglutinin dari virus atau bakteri.

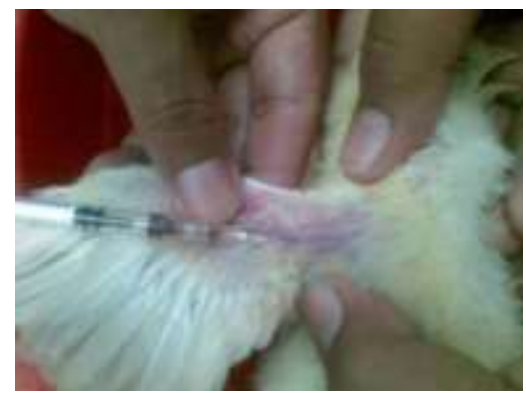

Gambar 1 Pengambilan darah sampel untuk uji serologi

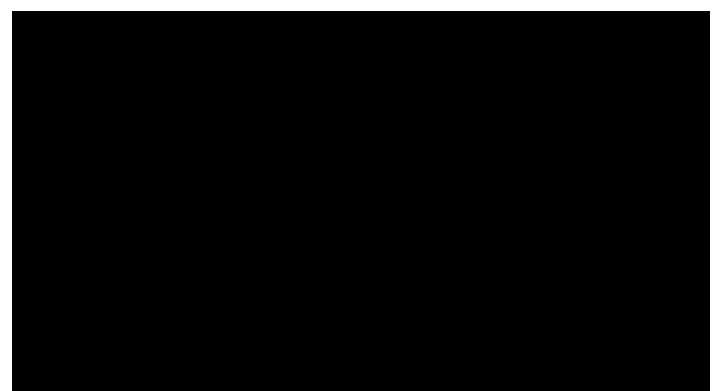

Gambar 2 Hasil HI test ditunjukkan dari ada tidaknya proses aglutinasi. $(\mathrm{A}=$ terjadi aglutinasi dan $\mathrm{B}=$ tidak terjadi aglutinasi)

HI test menggunakan reaksi hambatan haemaglutinasi tersebut untuk membantu menentukan diagnosa penyakit secara laboratorium dan mengetahui status kekebalan tubuh (titer antibodi, red). Prinsip kerja dari HI test ialah mereaksikan antigen dan serum dengan pengenceran tertentu sehingga dapat diketahui sampai pengenceran berapa antibodi yang terkandung dalam serum dapat menghambat terjadinya aglutinasi eritrosit. HI test merupakan metode uji serologis yang mudah dilakukan dan hasilnya dapat diketahui dengan cepat.

\section{Uji in vivo performans ayam jantan yang diberi probiotik}

Ayam jantan tipe medium Strain CP, sebanyak 48 ekor dipelihara sejak umur $1-31$ hari. Ayam diberi probiotik setiap unit percobaan ada 3 ekor dengan 4 ulangan setiap perlakuan. Perlakuan terdiri dari T0 sebagai kontrol tanpa pemberian probiotik, T1 =pemberian probiotik $2 \mathrm{x} /$ minggu selama dua minggu, $\mathrm{T} 2$ =pemberian probiotik $2 \mathrm{x} /$ minggu selama tiga minggu, $\mathrm{T} 3$ =pemberian probiotik $2 \mathrm{x} /$ minggu selama empat minggu, probiotik merupakan campuran dari isolat-isolat BAL (B1, B3, B4, B5). Pertambahan bobot badan ayam percobaan dihitung berdasarkan bobot badan umur 31 hari dikurangi bobot badab ayam umur 24 hari dengan menimbang setiap perlakuan pada setiap 6 hari. Ransum yang diberikan ayam berupa BR1 secara adlibitum. Feed Convertion Ratio (FCR) dihitung berdasarkan jumlah ransum yang dikonsumsi selama 6 hari dibagi dengan pertambahan bobot badan pada minggu yang sama.

\section{HASIL DAN PEMBAHASAN}

\section{Pengamatan dinamika populasi isolat BAL untuk probiotik}

Isolat B1, B3, B4, B5 digunakan dan dirakit sebagai probiotik, secara in vitro ditumbuhkan dalam media MRS Agar+Ransum BR1. Hasil uji in vitro dan in vivo untuk mengetahui kemampuan pertumbuhan probiotik oleh adanya pengaruh campuran ransum ayam BR1 yang mengandung Coccidiostat (antibiotik) disajikan dalam Tabel 1 dan 2. Didapatkan hasil pertumbuhan isolat pada MRSAgar. Koloni yang tumbuh pada pengenceran $10^{-3}$, dan $10^{-4}$ tidak dapat dihitung, sedangkan pada 
Rudy Sutrisna: Isolat Bakteri Asam Laktat Sebagai Probiotik dengan Vaksinasi AI Dan ND...

media MRSAgar+BR1 jumlah koloni 196-204 x $10^{-4}$ dan 291-339 x $10^{-3}$ CFU per ml suspensi probiotik.

Tabel 1. Respon pertumbuhan isolat campuran B1, B3, B4 dan B5 (CFU/ml) in vitro

\begin{tabular}{ccc}
\hline \multirow{2}{*}{ Pengenceran } & \multicolumn{2}{c}{ Pertumbuhan koloni isolat campuran } \\
\cline { 2 - 3 } & MRSAgar + BAL campuran & MRSA+BAL campuran+BR1 \\
\hline \multirow{2}{*}{$10^{-3}$} & $>300$ & 291 \\
& $>300$ & 339 \\
$10^{-4}$ & $>300$ & 196 \\
& $>300$ & 204 \\
\hline
\end{tabular}

Keterangan: BR1 = Ransum komersial yang mengandung Coccidiostat.

Koksidiosis menyebabkan kerugian ekonomi yang cukup besar dalam industri unggas. Ayam yang rentan terhadap 11 spesies coccidia, spesies yang paling umum adalah Eimeria tenella, yang menyebabkan jenis perberdarah sekum, E. necatrix, yang menyebabkan koksidiosis usus berdarah, dan E. acervulina dan E. maxima yang menyebabkan koksidiosis usus kronis. Eimeria tenella berkembang dalam sel-sel sekum, pada dua kantung buntu dekat bagian akhir dari usus (ilium). Parasit ini adalah salah satu yang paling patogen karena memproduksi coccidia untuk menginfeksi ayam. Infeksi akut ini terjadi paling sering pada anak ayam muda. Infeksi dapat ditandai dengan adanya darah dalam kotoran dan dengan morbiditas dan mortalitas yang tinggi.

Oleh karena itu ransum komersial seperti BR1 yang digunakan untuk pembesaran ayam jantan selalu mengandung Coccidiostat (suatu antibiotik penghambat parasit koksidiosis). Dengan demikian probiotik yang diintroduksikan secara in vitro menunjukkan tahan terhadap Coccidiostat yang terdapat di dalam ransum BR1 yang ditandai oleh adanya pertumbuhan isolat campuran dalam saluran pencernaan ayam.

Tabel 2. Dinamika isolat BAL sebagai probiotik pada ayam umur 31 hari

\begin{tabular}{lcccc}
\hline \multirow{2}{*}{$\begin{array}{c}\text { Organ saluran } \\
\text { pencernaan }\end{array}$} & \multicolumn{4}{c}{ Jumlah koloni per perlakuan pemberian probiotik (CFU/ml) } \\
\cline { 2 - 5 } & $\begin{array}{c}2 \times / \text { minggu selama } \\
\text { seminggu }\end{array}$ & $\begin{array}{c}2 \times / \text { minggu selama } \\
\text { dua minggu }\end{array}$ & $\begin{array}{c}2 \times / \text { minggu selama } \\
\text { tiga minggu }\end{array}$ & $\begin{array}{c}2 \times / \text { minggu selama } \\
\text { empat minggu }\end{array}$ \\
\hline Ilium & $4,3 \times 10^{-6}$ & $10,6 \times 10^{-6}$ & $2,3 \times 10^{-6}$ & $14,0 \times 10^{-6}$ \\
Jejenum & $1,9 \times 10^{-6}$ & $9,7 \times 10^{-6}$ & $13,5 \times 10^{-6}$ & $2,4 \times 10^{-6}$ \\
\hline
\end{tabular}

Keterangan: Probiotik = campuran isolat BAL (B1, B3, B4, B5)

Berdasarkan penelitian yang dilakukan oleh Sutrisna dan Nurjanah (2010) diperoleh 20 isolat bakteri usus itik yang diketahui 13 isolat diantaranya dapat menghambat pertumbuhan bakteri Salmonella pullorum. Penelitian yang dilakukan oleh Rahmawati (2012), dari ke 13 isolat tersebut didapat 4 jenis isolat dengan kemampuan terbesar dalam menghambat pertumbuhan bakteri Escherechia coli dan Salmonella pullorum yaitu isolat dengan kode B1, B3, B4, dan B5. Berdasarkan kemampuannya dalam menghambat pertumbuhan bakteri maka isolat tersebut sebagai kandidat probiotik. 
Jurnal Penelitian Pertanian Terapan

\section{Pengamatan uji daya hidup probiotik dalam medium aquades}

Daya hidup isolat diamati untuk mengetahui daya tahan hidupnya dalam suatu media seperti aquades atau air sumur yang biasa digunakan sebagai air minum ayam jantan tipe medium. Hal ini dilakukan untuk mengetahui jika isolat tersebut diterapkan sebagai probiotik maka lebih praktis dicampurkan ke dalam air minum ayam. Berdasarkan hasil uji didapatkan kemampuan hidup atau daya hidup isolat dalam medium aquades disajikan dalam Tabel 3.

Berdasarkan Grafik 1, pada inkubasi (0 , 24, 48, dan 72 jam) menunjukkan jumlah koloni isolat B1 sama banyak pada media aquades. Respon isolat B3 pada inkubasi (24 jam) mengalami penurunan jumlah dan berbeda lebih sedikit jumlahnya daripada isolat B1, tetapi kemudian meningkat pada inkubasi (48 dan 72 jam). Isolat B4 pada inkubasi awal (0 jam) dengan (48 jam) sama jumlahnya, tetapi pada 24 jam inkubasi turun, dan naik lagi pada 72 jam dengan jumlah yang sama pada inkubasi 24 jam. Isolat B5 pada inkubasi awal (0, 24, 48 jam) sama jumlahnya, sedangkan pada 72 jam mengalami penurunan jumlah. Isolat B5 inkubasi $(0,24,48$ jam) sama jumlahnya dengan isolat B3 pada inkubasi 24 jam, tetapi berbeda dengan isolat lainnya.

Tabel 3. Hasil uji daya hidup isolat dalam media aquades (CFU/ml)

\begin{tabular}{ccccc}
\hline \multirow{2}{*}{ Waktu inkubasi } & \multicolumn{4}{c}{ Jumlah koloni Isolat BAL $(\log )$} \\
\cline { 2 - 5 } & B1 & B3 & B4 & B5 \\
\hline 0 jam & 10.498 & 8.883 & 9.466 & 7.388 \\
24 jam & 10.398 & 7.815 & 8.439 & 7.350 \\
48 jam & 10.497 & 8.750 & 9.436 & 7.460 \\
72 jam & 10.477 & 8.389 & 7.885 & 6.413 \\
\hline
\end{tabular}

Respon isolat ditinjau dari daya hidup (mampu membentuk koloni) pada media aquades merupakan fenomena yang menguntungkan apabila isolat digunakan sebagai probiotik. Espektasinya adalah probiotik yang diterapkan melalui air minum akan dapat tumbuh dengan baik di saluran pencernaan ayam. Hal ini disebabkan oleh kondisi di dalam saluran pencernaan akan tersedia nutrien yang lebih lengkap bagi pertumbuhan isolat. Menurut Mitsuoka (1980), Salanitro (1974) dan Barnes (1986) total bakteri di bagian sekum broiler berkisar antara 10,5-10,9 Log10 CFU/g. Oleh karena itu populasi BAL sebagai isolat dalam saluran pencernaan ayam jantan tipe medium memungkinkan untuk dapat meningkatkan status kesehatan ayam.

Gambar 3. Uji daya hidup isolat BAL kandidat probiotik dalam aquades 
Rudy Sutrisna: Isolat Bakteri Asam Laktat Sebagai Probiotik dengan Vaksinasi AI Dan ND...

\section{Pengamatan pembentukan titer antibodi}

Berdasarkan hasil analisis laboratorium uji antibodi yang terbentuk menunjukkan bahwa perlakuan pemberian probiotik pada ayam yang divaksin AI dihasilkan titer antibodi paling tinggi pada (T3-U2) dengan nilai rata-rata titer Haemaglutination Inhibition (HI) $\geq 2^{4}(\geq 16)$. Gambaran titer antibodi (angka kekebalan) ayam dari hasil uji serologi yang secara rutin dilakukan inilah yang disebut dengan monitoring titer antibodi. Dengan demikian terdapat sinergi antara pemberian probiotik terhadap pembentukan titer antibodi pada perlakuan (T3-U2).

Menurut rekomendasi organisasi kesehatan dunia (OIE), tingkat antibodi yang protektif terhadap penyakit Avian Influenza (AI) bernilai $\geq 2^{4}(\geq 16)$, yaitu tingkat titer antibodi yang menunjukkan kekebalan hewan terhadap infeksi (Alfons, 2005). Oleh karena hasil percobaan didapatkan nilai titer antibodi $\mathrm{AI} \geq 2^{2}(\geq 4)$ pada perlakuan tanpa pemberian probiotik sehingga dapat dinyatakan bahwa vaksinasi tidak cukup berhasil. Perlakuan T2-U1 dan T4-U1 titer antibodinya mencapai $\geq 2^{3}(\geq 8)$, menunjukkan kurang kebal terhadap infeksi AI. Pengamatan titer antibodi sampel serum ayam umur 31 hari atau 4 minggu dilakukan setelah vaksinasi. Waktu pengamatan titer antibodi AI serum ayam percobaan, masih pada awal pembentukan antibodi yaitu pada posisi 7 hari kondisi maternal antibodinya (mat $\mathrm{Ab}$ ) pada kondisi terendah, sehingga masih dimungkinkan untuk meningkat nilai titernya pada umur lebih tua. Pada vertebrata, antibodi induk (matAb) ditransfer dari induk, melalui kuning telur atau susu selama menyusui untuk anak sampai 2 minggu pada burung/unggas, sedangkan pada tikus 4-10 minggu (Hasselquist dan Nilsson, 2014)

Ayam yang divaksin atau terinfeksi virus lapangan akan terbentuk antibodi ( $\operatorname{Ig} \mathrm{A}, \operatorname{IgG}$ dan $\operatorname{IgM})$. $\mathrm{IgG}$ ialah antibodi utama dalam serum. Antibodi ini terdeteksi paling cepat 7 hari post infeksi/vaksinasi. Uji serologi dapat dipakai untuk membantu menentukan adanya infeksi lapangan atau dari hasil kerja vaksin. Contohnya ayam layer umur 60 hari yang belum pernah divaksin AI. Hasil uji serologi terdeteksi adanya titer antibodi AI. Hal ini mengindikasikan adanya virus AI lapangan (Info Medion, 2008).

Kondisi titer antibodi tidak akan selamanya protektif, setelah beberapa periode waktu, titer antibodi di dalam tubuh ayam akan menurun dan kecepatan penurunan titer antibodi ini dipengaruhi oleh tantangan bibit penyakit maupun kondisi ternaknya. Agar pembentukan titer antibodi bisa mencapai optimal maka pelaksanaan vaksinasi harus dilakukan secara tepat. Vaksin yang digunakan dalam penelitian ini adalah vaksin ND dalam bentuk inaktif. Vaksin inaktif tidak mempunyai kemampuan untuk berkembang biak di dalam tubuh hewan yang divaksinasi, tetapi mampu merangsang pembentukan antibodi. Kelompok vaksin ND aktif mesogenik baik digunakan untuk vaksinasi ulangan oleh karena virulensinya yang masih lumayan tinggi (Van Eck et al, 1999). Walaupun demikian, kelompok vaksin ND lentogenik juga bervariasi dalam virulensinya, yang diukur berdasarkan indeks stress yang terjadi setelah pelaksanaan vaksinasi ND. Respon imun juga meningkat sejalan dengan meningkatnya patogene-sitas dari virus vaksin (Kapczynski et al. 2005).

Nilai titer dengan keseragaman hasil didapatkan pada perlakuan T3 -U1, T3-U2 yaitu pemberian probiotik 2 kali per minggu selama 3 minggu, dihasilkan terbaik, dengan rata-rata $\mathrm{HI} 2^{4}$. Hasil titer $2^{4}$ pada T3 lebih seragam sehingga dapat dinyatakan keberhasilan vaksinasi terbaik. Perlakuan T3-U1 tercapai $2^{3}$, bahkan T2-U2 mencapai $2^{7}$ meskipun termasuk standar efektifitas antibodinya tinggi tetapi tidak seragam. Menurut Allan et al (1978) titer antibodi ND terbagi tiga yaitu (1) jika nilai titer antibodi ND $2^{0}$, tingkat mortalitas $100 \%$, (2) nilai titer antibodi ND $2^{2}-2^{5}$ tingkat 
Jurnal Penelitian Pertanian Terapan

mortalitasnya $10 \%$, (3) nilai titer antibodi ND $2^{4}-2^{6}$ tingkat mortalitasnya 0\%. Meskipun demikian, karena pengamatan nilai titer ini dilakukan pada masa awal diteksi titer antibodi pada umumnya maka masih dimungkinkan adanya peningkatan nilai titer antibodi pada umur ayam lebih tua.

\section{Uji in vivo pertumbuhan ayam jantan yang diberi probiotik}

Uji probiotik secara in vivo dilakukan kepada ayam jantan tipe medium umur $1-31$ hari. Introduksi probiotik pada tingkat pemberian probiotik $2 \mathrm{x} /$ minggu selama satu minggu (T1), $2 \mathrm{x} /$ minggu selama dua minggu (T2), 2x/minggu selama tiga minggu (T3), dan tanpa probiotik sebagai kontrol (T0) menghasilkan pertambhan bobot badan disajikan pada Tabel 4. Perlakuan ini untuk mengetahui respon probiotik terhadap pertambahan bobot badan yang dihasilkan ayam percobaan. Ayam jantan yang diberi perlakuan T0 - T3 berbeda berdasarkan Grafik 1 bahkan menunjukkan linier artinya semakin tinggi penggunaan probiotik menghasilkan pertambhan bobot badan meningkat. Probiotik yang berperan sebagai antibakteri patogen menunjukkan dapat menjaga status kesehatan sehingga dihasilkan pertambahan bobot badan berkisar 75,83 — 89,04 g pada pemeliharaan umur 24-31 hari. Perlakuan T0 sama dengan T1 dan berbeda dengan T2 dan T3, data bobot badan disajikan pada Tabel 4.

Tabel 4. Performans ayam umur 24--31 hari

\begin{tabular}{lcccc}
\hline & \multicolumn{4}{c}{ Perlakuan probiotik } \\
\cline { 2 - 5 } \multicolumn{1}{c}{ Performans } & $\begin{array}{c}\text { 2x/minggu } \\
\text { selama seminggu }\end{array}$ & $\begin{array}{c}2 \mathrm{x} / \text { minggu } \\
\text { selama dua } \\
\text { minggu }\end{array}$ & $\begin{array}{c}\text { 2x/minggu } \\
\text { selama tiga } \\
\text { minggu }\end{array}$ & $\begin{array}{c}\text { 2x/ minggu } \\
\text { selama empat } \\
\text { minggu }\end{array}$ \\
\hline Bobot Badan umur 31 hari (g) & 329,16 & 325,54 & 324,08 & 328,54 \\
Bobot Badan umur 24 hari (g) & 253,33 & 249,00 & 242,50 & 239,50 \\
Pertambahan Bobot Badan (g) & 75,83 & 76,54 & 81,58 & 87,04 \\
Feed Intake (g/ekor/6 hari) & 176,83 & 171,67 & 175,00 & 172,50 \\
FCR & 2,33 & 2,24 & 2,15 & 1,98 \\
\hline
\end{tabular}

Standar bobot badan ayam jantan tipe medium pada umur 28 hari berkisar 300-335,00 g/ekor dan 28-35 hari 300 - 400 g/ekor (Rama Jaya, 2009). Hasil penelitian menghasilkan bobot badan sesuai dengan standar yaitu mencapai bobot badan 324,08-329,16 g/ekor. Fenomena sinergi didapatkan pada perlakuan T0 (tanpa probiotik) dan T3 (dengan pemberian probiotik 2x/minggu selama 3 minggu) menghasilkan pertambahan bobot badan yang meningkat. Hal ini menunjukkan bahwa pemberian probiotik $2 x /$ minggu selama 3 minggu, merupakan dosis yang terbaik yang dapat menunjang pertumbuhan normal serta pertambahan bobot badan tertinggi. Hal ini dikuatkan pada pengamatan dinamika isolat di ilium menghasilkan populasi koloni isolat terbanyak, serta titer antibodi seragam. 
Rudy Sutrisna: Isolat Bakteri Asam Laktat Sebagai Probiotik dengan Vaksinasi AI Dan ND...

Grafik 2. Pertambahan bobot badan ayam jantan umur 24-31 hari

\section{KESIMPULAN}

Isolat B1, B3, B4 dan B5 kandidat probiotik yang dirakit secara invitro sebagai probiotik dapat tumbuh pada media yang dicampur ransum BR1 bercoccidiostat sebagai antibiotik. Probiotik menghasilkan dinamika pertumbuhan di ilium mencapai $14 \times 10^{-6}$ dan jejunum $13,5 \times 10^{-6} \mathrm{CFU} / \mathrm{ml}$. Selain itu dapat hidup dalam inkubasi media aquades dari 0-72 jam, sehingga dapat diterapkan sebagai probiotik dengan cara dicampurkan dalam air minum ayam.

Keberhasilan vaksinasi AI dan ND dihasilkan titer antibodi terbaik tercapai pada T3 (ayam diberi probiotik 2x/minggu selama 3 minggu), menunjukkan adanya keseragaman pembentukan titer antibodi ND. Fenomena ini menunjukkan adanya sinergi antara pemberian probiotik dengan terbentuknya titer antibodi ND.

Respon performan ayam jantan yang diintroduksi probiotik menghasilkan bobot badan umur 31 hari berkisar 313,54-329,17 g/ekor masuk standar normal pencapaian bobot badan, dan pertambahan bobot badan tertinggi 87,04 g pada perlakuan T3.

\section{SARAN}

Introduksi probiotik sebaiknya diterapkan pada ayam jantan yang diberi ransum tanpa antibiotik, sehingga dihasilkan ayam organik. Dosis pemberian probiotik perlu dicari yang lebih efektif terhadap berbagai respon (performan, dan titer antibodi). Perlu identifikasi antibakteri yang dihasilkan oleh isolat BAL sebagai probiotik.

\section{UCAPAN TERIMAKASIH}

Penelitian ini dapat terlaksana karena dukungan biaya dari HIBAH BERSAING tahun anggaran 2013. Atas dukungannya saya ucapkan terimakasih. 
Jurnal Penelitian Pertanian Terapan

\section{DAFTAR PUSTAKA}

Alfons, M. P. W. 2005. Pengaruh Berbagai Metode dan Dosis terhadap Efikasi Vaksin Avian Influenza (AI) Inaktif. [Skripsi]. Bogor; FKH IPB.

Allan, J. E., Lancaster and B. Toth. 1978. Newcastle Disiase Vaccines. Their Production and Use. Food and Agricultural Organisation. Rome.

Astawan, M. 2005. Trend Makanan 2005. www.yahoo/kesehatan. Diakses 24 Januari 2005. Barnes, E.M. 1986. In Bacteria in Habitats Other Than Man. pp 225-228.

Hasselquist, D. dan J.A. Nilsson. 2014. Transfer Maternal Antibodi dalam Vertebrata: efek transgenerasi pada imunitas keturunan. Diakses 23 Feb. 2014; http://www.ncbi.nlm.nih. gov/pmc/articles/PMC2666691/

Info Medion, 2008. Metode Uji Serologi. Diakses 11 Maret 2013. info Medion Edisi Juli 2008. (http://info.medion.co.id)

Kapczynski, D. R. and D. J. King, 2005. Protection of Chickens Against Overt Clinical Disease and Determination of Viral Shedding Following Vaccination With Commercially Available Newcastle Disease Virus Vaccines Upon Challenge With Highly Virulent Virus From the California 2002 exotic Newcastle Disease Outbreak. Vaccine. 23: 3424-3433.

Mitsuoka, T. 1980. In Proceedings of the International Symposium of Anaerobes. pp 53-57. Tokyo, Japan: Nippon Merck-Banyu.

Rahmawati, D. 2012. Karakterisasi dan Uji Daya Antibakteri Isolat Bakteri Asam Laktat dari Usus Itik (Anas domestica) terhadap Escherichia coli dan Salmonella pullorum. [Skripsi] Jurusan Biologi MIPA Unila. Bandar Lampung.

Ramajaya, 2009. Standar Performans Produksi Ayam Jantan Petelur per 1000 ekor. Bandar Lampung.

Roberfroid, M. B. 2000. Concept and Strategy of Food Science. The Europan Perspective. Am. J. Clin Nutr. (71) 6: 1660-1664.

Salanitro, J. P., Blake, I. G., Muirhead, P. A., 1974. Studies on the cecal microflora of commercial broiler chickens. Appl. Microbiol. 28, 439-447.

Sutrisna, R., S. Nurjanah. 2010. Isolasi non-starch Polysacharides sebagai Prebiotik dan Bakteri sebagai Probotik dalam Sistem Pencernaan Itik. Laporan Penelitian hibah bersaing tahun 2010. Fakultas Pertanian Universitas Lampung: Bandar Lampung

Van Eck, J. H. H., and E. Goren. 1999. An Ulster 2C Strain-Derived Newcastle Disease Vaccine: Vaccinal Resction in Comparison With Other Lentogenic Newcastle Disease Vaccine. Intern. J. Poultry Science 20. 497-508. 